\title{
ЛИТЕРАТУРОВЕДЕНИЕ
}

УДК 821.161.1.

\section{А.Г. Козлова}

\section{МУЗЫКА В ПОЭЗИИ ЮРИЯ ЛЕВИТАНСКОГО}

\section{А.Г. КОЗЛОВА. МУЗИКА В ПОЕЗІЇ ЮРІЯ ЛЕВІТАНСЬКОГО.}

Стаття присвячена дослідженню особливостей втілення музичної теми і музичних образів у творчості Ю. Левітанського, поезія якого має яскраво виражений інтермедіальний характер і трунтується на синтезі різних видів мистецтва - кіно, музики і живопису. Зокрема, про органічний зв'язок поезії Левітанського з музикою красномовно свідчить той факт, що цілий ряд віршів поета отримав назву "Пісенька ...» або "Пісня ...». Саме життя у поета нерідко співвідноситься з музичними формами, щяо знаходить відображення в таких назвах творів, як «Босса Нова о нескончаемом дне», «Весеннего леса каприччо...» та ін. У творчості Левітанського музика стає втіленням самого життя, символом природного ииклу. У віршах, де життя людини уподібнюється дорозі, поет також не обходиться без музичної теми, музичних образів. Навіть вірші соиіально-політичної проблематики зв'язуються у Левітанського з темою музики. Музика в його творчості стає однією з основ і світобудови земних і небесних сфер, людського існування, різних аспектів людського буття, виявляючи ідею єдності всього сущчого і неподільності світу. Іноді сама назва вірша вказує на характерну для поета ідею нерозривності природного $i$ музичного начал («Вальс на мотив метели»). Відзначаючи органічний зв 'язок поезії Левітанського з музикою, ми звертаємо увагу на те, що в творчій свідомості поета музика стає символом і самою основою життя, втіленням глибинної таємниці буття, загальної гармонії. Тож не дивно, що і сама музика у Левітанського нерідко антропоморфізуєтся, набуває властивостей, якостей живої істоти.

Ключові слова: творчість Ю. Левітанського, інтермедіальність, синтез, поезія, музика, музичні образи.

\section{А.Г. КОЗЛОВА. МУЗЫКА В ПОЭЗИИ ЮРИЯ ЛЕВИТАНСКОГО.}

Статья посвящена исследованию особенностей воплощения музыкальной темы $и$ музыкальных образов в творчестве Ю. Левитанского, поэзия которого имеет ярко выраженный интермедиальный характер и основана на синтезе различных видов искусства кино, музыки и живописи. В частности, об органической связи поэзии Левитанского с музыкой красноречиво свидетельствует тот факт, что чельй ряд стихотворений поэта получил название «Песенка...» или «Песня...». Сама жизнь у поэта нередко соотносится с музыкальныли формами, что находит отражение в таких названиях произведений, как «Босса Нова о нескончаемом дне», «Весеннего леса каприччо...» и др. В творчестве Левитанского музыка становится воплощением самой жизни, символом природного иикла. $B$ стихотворениях, где жизнь человека уподобляется дороге, поэт также не обходится без музыкальной темы, музыкальных образов. Даже стихотворения социально-политической проблематики связываются у Левитанского с темой музыки. Музыка в его творчестве становится одной из основ и мироздания - земных и небесных сфер, человеческого существования, разных аспектов человеческого бытия, обнаруживая идею единства всего сущего и слитности мира. Иногда само название стихотворения указывает на характерную для поэта идею неразрывности природного и музыкального начал («Вальс на мотив метели»). Отмечая органическую связь поэзии Левитанского с музыкой, мы обращаем внимание на то, что в творческом сознании поэта музыка становится символом и самой основой жизни, воплощением глубинной тайны бытия, всеобщей гармонии. Не удивительно, что и сама музыка у Левитанского нередко антропоморфизируется, приобретает свойства, качества живого существа.

Ключевые слова: творчество Ю. Левитанского, интермедиальность, синтез, поэзия, музыка, музыкальные образы.

() А.Г. Козлова, 2019

https://doi.org/10.34142/2312-1572.2019.02.68.08 


\section{A.G. KOZLOVA. MUSIC IN YURY LEVITANSKY'S POETRY.}

The article is devoted to the study of special aspects of musical images realization in the creative works of Yury Levitanksy, whose poetry has strong influence of intermedia based on the synthesis of various spheres of art such as cinema, music and pictorial art. The natural connection of Levitansky's poetry and music can be easily observed in the names of a number of his poems named "Tune..." or "Song...". The life of the poet itself is often described as having musical connection. This fact is reflected in such names as "Bossa Nova in an endless day", "The capriccio of a springtime forest...", etc. In Levitansky's works music becomes the embodiment of life itself, a symbol of the natural cycle. In his poems, where human life is compared to a pathway, the poet also uses musical themes and musical images. Even the poems of social and political issues are associated with the theme of music in Levitansky. Music in his poems is one of the basic powers of the universe, material and ethereal aspects, the existence of humanity, separate areas of human lives. It possesses the idea of global inclusion. In some cases the name of a poem can refer to the idea of inseparability of music and nature ("Waltz to the tune of a blizzard").

Noting the organic connection of Levitansky's poetry with music, the attention is drawn to the fact that in the creative consciousness of the poet, music becomes a symbol and the very foundation of life, the embodiment of the deepest mystery of being, universal harmony. It is not surprising that Levitansky's music itself is often anthropomorphic, acquiring the qualities and attributes of a living being.

Key words: Yury Levitansky's creative work, intermedia, synthesis, lyric poetry, music, musical images.

В статье «Музыка в лирике Булата Окуджавы» [3] мы отмечали неслучайность посвящения Ю. Левитанскому стихотворений Окуджавы, связанных с музыкальной темой. И действительно, в творчестве этого поэта музыкальная тема и музыкальные образы не только весьма частотны, но занимают чрезвычайно важное место в его картине мира. Достаточно вспомнить такие произведения, апеллирующие к музыкальной стихии, как «Музыка, свет не ближний...», «Я люблю эти дни...», «Музыка моя, слова...», «Музыка», «Трубач», «Воспоминанье о скрипке», «Воспоминанье о шарманке», «Сон о рояле», «Вальс на мотив метели» и ряд других.

И критики, и собратья по перу давно обратили внимание на интермедиальный характер поэзии Левитанского, характерный для нее синтез искусств (см., например: [1]; [4]; [8]). В частности, К.С. Лицарева отмечает, что «особенностью поэтического видения Левитанского является тесное сцепление в его сознании трех видов искусства: кино, музыки и живописи [8, c. 11].

В.А. Куллэ полагает, что «отношение поэта к музыке можно назвать “филологическим” - оно проявляется в мелодике стиха, в его ритмике, в композиционной изощренности, с которой Левитанский выстраивал свои книги-сюиты» [5].

Украинский поэт Мыкола Бажан сравнивал отдельные стихотворения Левитанского с фугами, а сам Левитанский признавался в интервью, что книга «Кинематограф» (1970) основана на принципе сонатного построения (аллегро, анданте, скерцо, аллегро) [9].

Указывая на симфонический принцип организации книги «Кинематограф», К.С. Лицарева проводит аналогию между ее четырехчастной композицией и «принципами сонатного построения, традиционно используемого и для симфоний», и выделяет такие части книги, как «1) аллегро - лето; 2) анданте - осень; 3) скерцо - зима; 4) рондо - весна» [8, с. 9]. Подобным образом трактует особенности построения «Кинематографа» и И.С. Кадочникова [2]. (К слову, о специфичности построения книг поэта писали многие исследователи, среди которых Л. Гомберг, С. Моско, М. Поздняев, С. Чупринин.) В то же время отдельных работ, посвященных особенностям воплощения музыкальной темы и музыкальных образов в творчестве Ю. Левитанского, нет. Исследование данной проблемы и стало целью нашей статьи.

Об органической связи поэзии Левитанского с музыкой довольно красноречиво свидетельствует тот факт, что целый ряд стихотворений поэта получил название «Песенка...» или «Песня...»: «Песенка старого клоуна», «Песенка для мамы. Старинное танго», «Песенка о часах», «Песенка о гитаре и трубе» и др., цикл «Песни городской рекламы». То же относится и к пародиям: «Песенка о зайце-самозванце, или о коте-дилетанте, написанная специально для Беллы в присутствии 3. Гердта и А. Райкина по мотивам А. Пушкина» (Б. Окуджава), «Песня о 
бумажном зайчике» (Б. Окуджава), «Будь здоров, гусляр! Песенка о поющем Булате» (Н. Коржавин). Да и сама жизнь у поэта нередко соотносится с музыкальными формами, что находит отражение в названиях произведений: «Босса Нова о нескончаемом дне», «Весеннего леса каприччо...» и др. (выделено нами. - А. К.).

Нередко музыка у Ю. Левитанского приобретает символическое значение, соотносясь с идеей жизни как таковой. Так, стихотворение «Время раскрывающихся листьев (фрагмент сценария)» (1970), повествующее о жизни, которая есть ...чудо непрерывности творенья, / сотворенья ветки и куста, / чудо воссозданья, / повторенья, / завершенья круга ..., открывается музыкальной темой. Музыка здесь становится и воплощением этого чуда, и самой первоосновой творенья: Клавиши рояля, чей-то палеи, / пробежавший по клавиатуре, / и сейчас же тысячи сосулек / с грохотом летят на тротуар [6, с. 87], словно незримый музыкант, играя, создает все сущее, все то, о чем повествуется в стихотворении, - и человека в весеннем сквере, и сам сквер с грачами, и старух, идущих мимо сквера, и играющих детей, и весенний дождик и гром.

В глубоко философском стихотворении «Я люблю эти дни...» (1976) музыка становится воплощением самой жизни, символом природного цикла. Лирический герой - человек, умудренный жизненным опытом, воспринимающий жизнь как акт творения (или творчества?), подчиняющийся вышнему замыслу, - признается: Я люблю эти дни, когда замысел весь уже ясен и тема угадана... [6, с. 176]. Это тот этап, который открывает такие глубины, / что становится ясной вся тайная суть естества [там же]. Завершение жизненного цикла уподобляется завершению исполняемого музыкантом или оркестром музыкального произведения. Не случайно уже в самом начале стихотворения упоминается «Прощальная симфония» Гайдна, ближе к финалу [там же]. Сама жизнь, с точки зрения поэта, - такая же симфония. И одним из основных принципов построения стихотворения становится параллелизм: ...nартитура листвы обгорает строка за строкой - / гаснут свечи в оркестре одна за другой <..> тихо гаснут березы одна за другой, догорают рябины [там же]. В приведенном фрагменте особое внимание обращает на себя генитивная метафора партитура листвы, соединяющая в себе музыкальное и природное начала. Существительное «партитура» имеет значение «совокупность партий многоголосного музыкального произведения (для оркестра, хора или ансамбля» [11, стлб. 232]). Таким образом, каждый элемент природы, буквально каждый листок, исполняет свою музыкальную партию, подчиняясь общему замыслу композитора. Философски воспринимая жизнь, и лирический герой, и сам поэт спокойно принимает естественное угасание осенней природы и человеческой (в данном случае собственной) жизни. Такая позиция напоминает строки известной песни на стихи Эльдара Рязанова: ...ход времен нельзя остановить. / Осень жизни, как и осень года, / надо, не скорбя, благословить $[10$, с. 34]. К слову сказать, строки эти написаны примерно тогда же, когда и стихотворение Левитанского (фильм «Служебный роман» вышел на экраны в 1977 году). Лирический герой Левитанского не просто смиренно принимает предписанный ход вещей, он спокойно относится к перспективе жизненного финала и дважды признается: Я люблю эти дни... Речь идет не только об осени как времени года, когда все так понятно в природе, так ясно и тихо кругом, но и о том этапе жизни, когда можно легко и спокойно подумать о жизни, о смерти, о славе, / и о многом другом... [6, с. 177]. Таким образом, тема жизни и смерти, аллегорически представленная в тексте стихотворения, находит в последних строках прямое вербальное выражение.

Не только в литературных произведениях, но еще на мифо-поэтическом уровне и в повседневном сознании жизнь человека уподобляется дороге (вспомним расхожее выражение «жизненный путь»). Такое уподобление характерно и для поэзии Левитанского. Причем и в этом случае поэт не обходится без музыкальной темы, музыкальных образов. Например, в стихотворении «Окрестности, пригород - как этот город зовется?..» человеческая жизнь уподобляется дороге, над которой в молодости «трубили походные трубы», которые для лирического героя, вступившего в пору зрелости, «давно оттрубили». В стихотворении «Сон о дороге», вошедшем в книгу «Кинематограф», вся история человечества предстает в виде долгой - в двести поколений - чреды идущих «из тьмы своих веков» по единому для всех пути в бесконечность. В конце стихотворения и сам лирический герой, подчинившись призывному «Проходи!!!», присоединяется к общей процессии, идет вслед за всеми. Музыкальная тема представлена здесь в используемых автором сравнениях: идущие - тысячи людей, одновременно произносящих одни и те же слова, - уподобляются греческому хору; лирический 
герой, присоединяющийся к общему движению, - музыкантам, уходящим с площади в конце военного парада [6, с. 80-81].

В стихотворении «Проторенные дороги» образ дороги не только ассоциируется с жизненным путем человека и человечества, но сливается с мотивом творчества многовекового, коллективного, и индивидуального, в котором это коллективное отражается и синтезируется; поэтического и музыкального (a, скорее, поэтического как музыкального): ...nовторенье до, повторенье ре, повторенье мифа, / до-ре-ми-фа-соль одним пальцем сто лет подряд. // И почти незаметное, медленное продвиженье, / передвиженье, медленное, на семь слогов, / на семь музыкальных знаков, передвиженье, / на семь изначальных звуков, на семь шагов [6, с. 112]. Здесь вновь звучит идея слитности мира, единства всего сущего - как в исторической перспективе, так и на любом новом витке истории и в каждой индивидуальной судьбе. Каждый человек идет проторенными дорогами, которыми прошли до него многие поколения людей, но это сложный путь медленного восхождения, ...дорога в горы, где каждый виток дороги / чуть выше, чем предыдущий ее виток [6, с. 113]. А история человечества - это и история его культуры: ...nередвиженье, медленное, на семь слогов, / на семь музыкальных знаков, передвиженье, / на семь изначальных звуков, на семь шагов (где в одном ряду оказывается словесное и музыкальное искусство). Об этом напоминает сакральное число семь: .... в конце дороги - <..> семь знаков, как семь ступенек, едва заметных, / семь звуков, как семь городов на семи холмах [там же]. В этом стихотворении музыка, музыкальная гармония часть гаммы - становится одновременно и основой, и символом этого продолжающегося и вечно повторяющегося исторического движения - жизни человечества и индивида: ...6 сумерках, одним пальщем, до-ре-ми-фа-соль, / и огарок свечи, и рояль, и опять, как вначале, - / до-ре-ми-фа-соль, до-ре-ми-фа-соль, до-ре-ми-фа-соль... [там же]. Музыка у Левитанского ассоциируется с гармонией мира, с идеей жизни как таковой. В стихотворении «Музыка» (1983) она выходит за пределы земного существования, приобретает поистине космические масштабы, становится воплощением глубинной тайны бытия, всеобщей гармонии. Не случайно печаль, являющаяся ее сутью, характеризуется как «неземная», «не здесь рожденная», а ее «владетель и хранитель» Моцарт становится «инопланетянином» [6, с. 242-243].

К.С. Лицарева отмечает, что, по мнению Левитанского, сами «музыкальные ритмы приходят из природы и дарят человеку ощущение смежности, неразрывности, бесконечности земного и космического бытия», в его поэзии «время и пространство как бы замыкаются в единый нерасторжимый круг, где тесно соприкасаются жизнь и искусство, мгновение и вечность, сон и явь, воспоминания и реальность, история и личность» $[8$, с. 7-8]. Как бы подтверждая эту мысль, в стихотворении «Весеннего леса каприччо...» поэт говорит о музыке, скрытой в эфире, / и в мире, лежащем окрест [6, с. 188]. Лицарева обращает внимание на то, что даже стихотворения, связанные с социально-политической проблематикой, «всегда сопряжены в творчестве Ю. Левитанского с темой музыки», и приводит в качестве примера такие его произведения, как «Сон о рояле» и «Это общество словно рояль...» $[8$, с. 7]. Таким образом, музыка у поэта становится одной из основ и мироздания - земных и небесных сфер, и человеческого существования, и разных аспектов человеческого бытия, обнаруживая идею единства всего сущего и слитности мира.

Неразрывность природного и музыкального начал отражается уже в самом названии стихотворения Левитанского «Вальс на мотив метели». Фантазия лирического героя в кружении белых снежинок на фоне черных деревьев (они же - черные на фоне белого неба) усматривает бал, кружение белых пар в новогоднем вальсе: ...белье девчонки в белых одеяньях. // Кружатся по кругу, положив на плечи / белым кавалерам белье руки... [6, с. 240-241]. И вновь в этом стихотворении по воле автора соединяются музыка, природа и человеческая жизнь.

Да и сама музыка у Левитанского - живая, одушевленная. В стихотворении «Музыка, свет не ближний...» поэт антропоморфизирует ее, используя риторические вопросы и форму императива, превращает не просто в объект риторического обращения, но поистине в живого собеседника, лирического адресата: Музыка, третий лишний, / что же ты, ну, беги! // Выдохлась? Притомилась? / Хочешь не хочешь - пой? < .. > Музыка, ну, не мешкай, / музыка, ну, беги! < .. > круг обеги и снова / встань впереди меня < .. > ... музыка, помоги! [6, с. 15-16].

Идея гармонии словесно-музыкального искусства и мира природы, «их единства и родства» воплощена в стихотворении «Музыка моя, слова...». Эта идея реализуется в первую очередь благодаря фонетическим средствам художественной выразительности, сближающим 
слово и музыку, придающим музыкальность стиху. Стихотворение отличается тщательно продуманной звуковой инструментовкой, основанной на подборе слов близкого звучания, активным использованием различного рода повторов, ассонансов и аллитераций, омонимии и паронимии:

\author{
музыка моя, слова, \\ осень, ясень, синь, синица, \\ сень ли, синь ли, сон ли снится, \\ сон ли синью осенится, \\ сень ли, синь ли, синева-
}

музыка моя, слова,

то ли поле, те ли ели,

то ли лебеди летели,

то ли выпали метели,

кровля, кров ли, покрова...

$<\ldots>$

синь, синица, синева [7].

Из четырех строф стихотворения три представляют собой пятистишие (квинтет) с редко встречающейся схемой рифмовки аббба. И только в последнем случае автор «отрывает» пятую строку, превращая строфу в соединение четверостишия и одностишия, которым и завершается стихотворение. В этом случае и схема рифмовки иная: абба $a$. Отметим, что вопрос о музыкальности лирики Левитанского требует отдельного пристального внимания исследователей.

Таким образом, идея слитности мира, общности музыки, природы, событий человеческой жизни и всего сущего в поэзии Левитанского является одной из ключевых. Еще одним наглядным примером ее воплощения может служить стихотворение «Воспоминанье о шарманке», повествующее о том, как появление шарманщика и «наивного и грустного» мотивчика приводило в движение «высокий и тесный» двор (он «оживал»: открывались окошки, в них появлялись лица и т.д.). Логика повествования развивается здесь от развертывания вполне реальной ситуации до фантазийной, в которой, благодаря музыке, рядом с копейкой, брошенной шарманщику из окна, появляются не только слезинка, улыбка и ромашка, но и синица, жар-птица, райская птица. Музыка становится основой творения - и поэтического текста, и мира. Не случайно поэтический труд («доброта моей работьл» [6, c. 106]) находит у Левитанского символическое воплощение в образе музыкального инструмента - свирели, дудочки [там же].

В стихотворении «Воспоминанье о скрипке» реалистическое начало преобладает над символическим, и, на первый взгляд, ему вполне подошло бы название «Воспоминанье о детстве», в котором есть место и бумажному кораблику, и хвойной ветке, и елочной игрушке, и польке, и скрипке... Вспоминая о своем детстве, лирический герой, кроме прочего, ассоциирует его с музыкальным началом - «шумными инструментами» шумового оркестра деревянными ложками, бутылками, гребенками, обернутыми папиросной бумагой, бутылками.

Таким образом, есть основания говорить не только об органической связи поэзии Левитанского с музыкой, но и о том, что в его творческом сознании музыка становится и символом, и самой основой жизни, воплощением глубинной тайны бытия, всеобщей гармонии. Отсюда - идея нераздельности природного и музыкального начал, музыки, природы и человеческой жизни. Не удивительно, что и сама музыка у Левитанского нередко антропоморфизируется, приобретает свойства, качества живого существа.

\title{
ЛИТЕРАТУРА
}

1. Кадочникова И.С. Синтез искусств в лирике Ю. Левитанского и А. Тарковского: дисс. ... канд. филол. наук: 10.01.01. Ижевск, 2011. 346 с.

2. Кадочникова И.С. «Я люблю эти дни, когда замысел весь уже ясен...» (структурные модели в книготворчестве Ю. Левитанского). Вестник Удмуртского университета. Серия: История и филология. 2008. Вып. 1. С. 169-178.

3. Козлова А.Г. Музыка в лирике Булата Окуджавы. Русская филология: Вестник Харьковского национального педагогического университета имени Г. С. Сковороды. 2018. № 3(65). C. 41-46. 
4. Колода Д.В. Интермедиальность текстов Юрия Левитанского (поэзия и/или кино). Вісник Харківського національного університету імені В.Н. Каразіна. № 1080. Серія «Філологія». Випуск 69. Харків, 2013. С. 85-89.

5. Куллэ В.А. Поэт личного стыда: Юрий Левитанский. Новый мир. 2001. № 11. URL: http://litinstitut.ru/content/poet-lichnogo-styda-yuriy-levitanskiy (дата обращения: 23.03.2019).

6. Левитанский Ю.Д. Годы: Стихи. М.: Советский писатель, 1987. 352 с.

7. Левитанский Ю.Д. Музыка моя, слова... URL: http://levitansky.ru/?r=2\&m=8\&s=233.

8. Лицарева К.С. Творчество Ю.Д. Левитанского в контексте современной поэзии (Проблематика. Поэтика): автореф. дис. ... канд. филол. наук: 10.01.02. Москва, 1994. 16 с.

9. Перемышлев Е. Левитанский, Юрий Давыдович. Энциклопедия Кругосвет. URL: https://www.krugosvet.ru/enc/kultura_i_obrazovanie/literatura/LEVITANSKI_YURI_DAVIDOVICH .html (дата обращения: 30.03.2019).

10.Рязанов Э.А. Любовь - весенняя страна. М.: Эксмо, 2007. 352 с.

11.Словарь современного русского литературного языка: в 17 томах. Т. 9. М.-Л.: Изд-во АН СССР, 1959, 1482 стлб.

(Статья поступила в редакциюю 10 марта 2019 г.) 